\title{
Unequal partnership: Sociolinguistics and the African American speech community
}

\author{
JOHN RUSSELL RICKFORD \\ Department of Linguistics \\ Stanford University \\ Stanford, CA 94305-2150 \\ rickford@csli.stanford.edu
}

\section{ABSTRACT}

American quantitative sociolinguistics has drawn substantially on data from the African American speech community for its descriptive, theoretical, and methodological development, but has given relatively little in return. Contributions from the speech community to sociolinguistics include the development of variable rules and frameworks for the analysis of tense-aspect markers, social class, style, narratives, and speech events, plus research topics and employment for students and faculty. The contributions which sociolinguistics could make in return to the African American speech community - but has not done sufficiently include the induction of African Americans into linguistics, the representation of African Americans in our writings, and involvement in courts, workplaces, and schools, especially with respect to the teaching of reading and the language arts. This last issue has surged to public attention following the Oakland School Board's "Ebonics" resolutions on Dec. 18, 1996.

The present unequal partnership between researcher and researched is widespread within linguistics. Suggestions are made for establishing service in return as a general principle and practice of teaching and research in our field. (African American Vernacular English, Ebonics, applications of sociolinguistics, community service, dialect readers, variation theory)*

This article provides me with the opportunity to talk about a subject that has been of growing concern to me for some years. Its starting point is that American quantitative sociolinguistics has, over the past quarter century, drawn substantially on data from African American Vernacular English (AAVE) and the African American speech community for its descriptive, theoretical, and methodological development, but it has given relatively little back to that community in terms of representation or practical application. While this article focuses on American quantitative sociolinguistics, in relation to AAVE, the criticism can be extended fairly easily to sociolinguis- 
tics more generally and to linguistics as a field, in relation to the peoples from whom we have drawn data for our theories and descriptions. So linguists from other sub-fields have no reason for complacency.

Before going on to develop my primary argument, I have a small preamble. In addressing this subject, I am reminded of the reason I originally got into linguistics, as an undergraduate at the University of California, Santa Cruz, at the end of the 1960s. The late Roger Keesing, an insightful linguistic anthropologist (see Keesing 1988), tantalized me into linguistics with his recordings of Solomon Islands Pijin and the radical conception (for me) that creole varieties like my native Guyanese Creole had systematic structure and fascinating, interconnected histories. But what really helped me to abandon English literature and design my own major in sociolinguistics was a paper by Le Page 1968 which dealt with the high failure rate $(70 \%$ to $90 \%)$ of Caribbean high school students on the English language GCE (General Certificate of Education) "O" level exam set by London and Cambridge Universities. Having worked as a high school teacher in Guyana for one year before setting off for college, I was aware of the problem, and I was convinced by Le Page's arguments that it resulted partly from the fact that teachers could not recognize the differences between local Creole and Standard English, nor help students to shift smoothly between the two varieties. As a solution to the problem, Le Page recommended that English language specialists should be trained to analyze their native varieties and help teachers improve their methods of teaching English. He outlined the training such specialists should have:

It is essential that these specialists have a thorough basic training in linguistics, psychological and sociological aspects of linguistic behavior, the psychology of language learning, the processes of creolization, the principles of contrastive analysis, and the structure of the languages involved in their situation (e.g. Creole English, Creole French, English, Spanish, Maya). They must also be trained in the general principles of education, in the preparation of teaching materials, and in the use of audio-visual aids, radio and television. (Le Page 1968:440)

Armed with Le Page's guidelines and assisted by a liberal and innovative college environment, I combined courses in linguistics, anthropology, and other fields, and graduated with a self-designed major in sociolinguistics in 1971. However, in a quarter century of working as a graduate student and university faculty member since then, I have focused mainly on descriptive, theoretical, and methodological issues rather than on the applied concerns which originally attracted me to the field. ${ }^{1}$ This is partly because of my excitement about the former kinds of research, and partly because of the process of appointment, tenure, and promotion - which rewards theory, and looks askance (if at all) at application. I suspect that, in this respect, my experi- 
ences are similar to those of many other sociolinguists; thus, the critique of this article is not just directed at others, but also at myself.

\section{CONTRIBUTIONS OF THE AFRICAN AMERICAN SPEECH COMMUNITY TO (SOCIO)LINGUISTICS}

The roots of American quantitative sociolinguistics were laid in 1958, in a paper by John Fischer in which the variation between -in and -ing as present participle suffixes (walkin/ing) was analyzed in the speech of 24 New England children. Fischer showed that these were not simply "free variants" - as mainstream linguistics then and now might regard them - but "socio-symbolic variants" systematically constrained by both internal and external factors including verb type, sex, and style. William Labov's studies of Martha's Vineyard (1963) and of New York City (the Lower East Side, 1966) built on these ideas; and with richer data and more significant theorizing about the relation between synchronic variation and change in progress, they essentially established the paradigm of quantitative sociolinguistics. Largely as a result of Labov's work, quantitative sociolinguistics became the dominant sub-field of sociolinguistics. ${ }^{2}$

Until W. Labov 1966, the speech of African Americans had played little if any role in the development of American sociolinguistics. But perhaps as an outgrowth of work by Stewart 1964 and Shuy 1965 which explored the relation among social dialects, non-standard speech, and the teaching of English, W. Labov et al. 1968 produced a two-volume study of the English of (primarily lower- and working-class) African Americans in Harlem, and this was studded with paradigm-setting innovations for the field. ${ }^{3}$ There were several other contemporaneous studies of AAVE, most of them similarly funded by the Office of Education and/or by private foundations interested in potential educational applications. The list includes studies in Detroit by Shuy et al. 1967 and Wolfram 1969, in Oakland by Mitchell-Kernan 1969, in Los Angeles by Legum et al. 1971, and in Washington, DC, by Fasold 1972. In the 1980s and 1990s, a new generation of urban studies was done in Los Angeles (Baugh 1983), in Philadelphia (W. Labov \& Harris 1986, Dayton 1994), in College Station, Texas (G. Bailey \& Maynor 1987), in East Palo Alto (Rickford et al. 1991), and in Detroit (Edwards 1992). Insofar as these later works were community studies and involved quantitative analyses of selected variables, they can be seen as extensions of the pioneering study by W. Labov et al. 1968, and they can be considered together in assessing the contributions which the study of AAVE bequeathed to sociolinguistics.

\section{Variable rules}

Despite its demonstration that structured variability was a part of language, W. Labov's 1966 study of the social stratification in NYC English did not 
attempt to represent such variability directly in linguistic structure; but the study by W. Labov et al. 1968 of AAVE in Harlem did, via the mechanism of variable rules with variable constraints (ibid., 12). Variable rules - represented notationally by a pair of angled brackets around the output of the rule, matched by at least one such pair in the conditioning environment went beyond conventional optional rules in specifying that a rule is more or less likely to apply depending on specified factors in the internal or extralinguistic environment. The variable which W. Labov 1969 used to introduce the concept of variable rules to the field was the contraction and deletion of the copula in AAVE, ${ }^{4}$ as in $\mathrm{He} 0$ nice, where the deletion was accounted for by the following rule: ${ }^{5}$

$$
[+ \text { cons }] \rightarrow\langle\theta\rangle /\left(\begin{array}{c}
{ }^{\text {strid }} \\
+ \text { cons } \\
+ \text { Pro }
\end{array}\right) \# \#\left[\begin{array}{c}
-\overline{\text { nas }} \\
+ \text { cont }
\end{array}\right] \# \#\left(\begin{array}{l}
+\mathrm{Vb} \\
+\mathrm{Fut} \\
-\mathrm{NP}
\end{array}\right)
$$

Copula absence in AAVE was to become legendary, insofar as it spawned and continues to spawn more synchronic and diachronic research in sociolinguistics than any other variable. Another AAVE variable - the simplification of word-final consonant clusters, especially $t$ and $d$ - also led to numerous studies. Copula absence in Harlem was one of three showcase variables used by Cedergren \& Sankoff 1974 to introduce VARBRUL, the widely used variable rule computer program. Both variables have played a role in the discussion of central theoretical and methodological issues in quantitative sociolinguistics, including the relation between individual and group grammars (Guy 1980 ), the relative ordering of variable rules (W. Labov 1969, Wolfram 1975, Romaine 1982), alternative procedures for computing rule applications and non-applications (Rickford et al. 1991, Blake 1997), the introduction of an exponential model (Guy 1991), and the relevance to variation studies of optimality theory (Guy 1994, Kiparsky 1994).

\section{Analysis of AAVE tense-aspect markers}

In addition to copula absence, several grammatical features of AAVE have been the focus of syntactic and semantic analysis by sociolinguists over the past quarter century, beginning with W. Labov et al. 1968 and with Fasold \& Wolfram 1970. The list includes the following tense-aspect markers (adapted from Rickford 1996):

(a) Absence of 3sg. present tense $-s$, as in He walkø for SE He walks (Fasold 1972:121-49).

(b) Use of invariant be to express habitual aspect, as in He be walkin for SE He is usually walking, usually walks (Fasold 1972:150-84, Green 1993).

(c) Use of stressed BIN to express remote phase, as in She BIN married for SE She's been married for a long time (and still is), or He BIN ate it for SE He ate it a long time ago (Rickford 1975, Baugh 1983:80-82, Green 1993). 
(d) Use of done to mark completive or perfective, as in He done did it for SE He's already done it (W. Labov 1972:55-56, Baugh 1983:74-77, Edwards 1991).

(e) Use of be done to mark resultatives or future/conditionals, as in She be done had her baby for SE She will have had her baby (Baugh 1983:7780, Green 1993, Dayton 1994).

(f) Use of finna (derived from fixin' to - see Ching 1987) to mark the immediate future, as in He's finna go for SE He's about to go.

(g) Use of steady as an intensified continuative marker (for actions that occur consistently and/or persistently), as in Ricky Bell be steady steppin' in them number nines (Baugh 1983:86).

(h) Use of come to express the speaker's indignation about an action or event, as in He come walkin' in here like he owned the damn place (Spears 1982:852).

(i) Use of had to mark the simple past or preterit, as in Then we had went outside for SE Then we went outside (Theberge 1988, Cukor-Avila \& Bailey 1995, Rickford \& Theberge-Rafal 1996).

Some of these features, like come and steady, were only reported in the literature at the beginning of the 1980s; preterit had, primarily used by preadolescents, was only discovered in the last decade. In addition to the discovery of new tense-aspect forms, there has been considerable recent discussion about the syntax and semantics of previously known AAVE tenseaspect markers like be and done (Martin 1992, Green 1993, Dayton 1994, Rickford \& Green 1997); however, some of this discussion draws on government and binding theory, rather than quantitative sociolinguistics.

\section{Relation to central sociolinguistic concepts}

More distinctively sociolinguistic are the ways in which AAVE data have contributed to the analysis of social class, ethnicity, network, and style within the quantitative paradigm. Contrary to what one might think, the number of full-fledged SOCIAL CLASs studies within sociolinguistics - especially those based on random samples - is rather small, and they date primarily from the 1960s. Of these, one of the most significant was Wolfram's (1969) study of AAVE in Detroit - which like its predecessor, Shuy et al. 1967, used a modified version of Hollingshead \& Redlich's 1958 education, occupation, and residency scales to yield a stratified random sample. ${ }^{6}$ Apart from its methodological innovations, this study was important in establishing that grammatical variables like multiple negation, copula absence, and absence of $3 \mathrm{sg}$. $-s$ tended to show sharp stratification, with major divisions between the middle and working classes; but phonological variables like consonant cluster simplification showed gradient stratification, with smoother transitions 
TABLE 1. Use of selected AAVE features in Detroit, by social class (adapted from Wolfram 1969)

\begin{tabular}{llllr}
\hline \hline Feature & LWC & UWC & LMC & UMC \\
\hline Multiple negation (p. 156) & $78 \%$ & $55 \%$ & $12 \%$ & $8 \%$ \\
Absence of copula/auxiliary is, are (p. 169) & $57 \%$ & $37 \%$ & $11 \%$ & $5 \%$ \\
Absence of 3sg. present tense $-s$ (p. 136) & $71 \%$ & $57 \%$ & $10 \%$ & $1 \%$ \\
Consonant cluster simplification NOT in past tense (p. 60) & $84 \%$ & $79 \%$ & $66 \%$ & $51 \%$ \\
\hline \hline
\end{tabular}

between classes (see Table 1). ${ }^{7}$ This pattern has been confirmed in several other studies (W. Labov et al. 1968, Rickford 1979), so much so that it is stated almost as a general principle in a recent sociolinguistics textbook (J. K. Chambers 1995:51). Most discussions of the role of ErHNICITY in sociolinguistics refer to research on AAVE and comparisons between Black and White Americans; see for instance Wolfram \& Clarke 1971, Giles 1979, Fasold 1981, Rickford 1985, as well as the coverage of ethnicity as a sociolinguistic variable in introductory texts like Holmes 1992, Trudgill 1995, and Hudson 1996.

With respect to the analysis of SOCIAL NETwORKs, L. Milroy 1980 is rightly given credit for the first substantive use of network theory in sociolinguistics. However, Labov et al. 1968 had effectively used sociometric diagrams a dozen years earlier to reveal the hang-out patterns of the Jets, Cobras, and other African American peer groups that they studied in Harlem; and other studies of African American communities (T. Labov 1982, W. Labov \& Harris 1986, Edwards 1992) have drawn on network theory and contributed to our understanding of its utility for the study of sociolinguistic variation.

With respect to the analysis of STYLISTIC VARIATION, it was in the study of Harlem by W. Labov et al. 1968 that Labov turned away from the combined use of interview contexts and channel cues which he had used in 1966 to distinguish CAREFUL and CASUAL styles. The 1968 work, inspired by the work of Gumperz in India and Norway, instead studied stylistic variation in the Harlem study through the contrast between individual interviews and peergroup sessions. Subsequently, there were several quantitative studies of stylistic variation according to addressee, but the theoretical conceptualization of style as AUDIENCE DESIGN only emerged in the work of Bell 1984. Rickford \& McNair-Knox 1994 tested some of Bell's predictions on the basis of repeated recordings of Foxy Boston, an African-American teenager from East Palo Alto. Bell's audience design model will undoubtedly continue to provoke discussion and research; but Foxy's AAVE data have, according to Bell (1995: 270), provided one of the most explicit investigations of a sociolinguistic model of stylistic variation to date. 


\section{Analysis of narratives and speech events}

Another area in which AAVE data have been helpful is the analysis of narratives and speech events. The definition of narrative and the framework for narrative analysis developed by W. Labov \& Waletzky 1967 , by W. Labov et al. 1968, and by W. Labov (1972:354-96), using narratives from African American youths and adults, have been widely adopted both within and without sociolinguistics, especially for the study of tense-aspect variation (see Schiffrin 1981, Fleischman 1990, Rickford \& Theberge-Rafal 1996). The definition includes reference to temporal ordering or juncture (a change in the order of two narrative clauses "will result in a change of the temporal sequence of their original semantic interpretation" - W. Labov 1972:360), and the framework includes recognition of the various structural components of narratives: abstracts, orientation and evaluation clauses, complicating actions, results, and codas.

Moreover, the study of speech events and discourse styles within the ethnography of speaking has perhaps advanced most steadily in relation to the study of speech events and styles within the African American speech community, through studies of sounding, signifying, marking, rapping, hip-hop language, and other speech events (Abrahams 1964, Mitchell-Kernan 1969, Kochman 1972, 1981, W. Labov 1972:297-353, H. Foster 1986, Smitherman 1986, 1995, M. Foster 1989, Morgan 1991, 1994b).

\section{Diachronic issues}

The main diachronic issues with which sociolinguists have concerned themselves, using AAVE data, are the creole hypothesis, the divergence hypothesis, and grammaticalization. The CREOLE ISSUE has to do with whether AAVE was once more different from Standard English and White vernacular dialects than it is now - in particular, whether it was a creole language similar to the Creole English spoken in Jamaica and other parts of the West Indies. In favor of the creolist view are B. Bailey 1965, Stewart 1970, Dillard 1972, 1992:60-92, Holm 1976, 1984, Rickford 1977, 1995, Baugh 1979, 1980, Rickford \& Blake 1990, Singler 1991, and Winford 1992a. More skeptical, however, are McDavid \& McDavid 1951, Poplack \& Sankoff 1987, Tagliamonte \& Poplack 1988, Poplack \& Tagliamonte 1991, Mufwene 1992, and Winford 1992b. No single socio-historical issue dominates annual NWAV and other sociolinguistics conferences as much as the creole issue (cf. Rickford 1995, Winford 1995), and it is likely to do so for years to come.

A more recent and perhaps equally unresolved issue is whether AAVE is currently DIVERGING from White vernaculars, becoming more different from them than it was, say, a quarter century ago. This view is favored by W. Labov \& Harris 1986 and by G. Bailey \& Maynor 1987. More skeptical, 
however, are some of the contributors in Fasold et al. 1987, as well as Butters 1989 and Rickford 1991. One difficulty is that, while the AAVE of the youngest generation shows divergence from White vernaculars with respect to some features, it shows convergence with respect to others. Interested readers should consult G. Bailey \& Maynor 1989, Butters 1989, and G. Bailey 1993 for further discussion.

The most recent diachronic issue to attract the attention of sociolinguists working on AAVE is GRAMMATICALIZATION, the process "through which a lexical item in certain uses becomes a grammatical item, or through which a grammatical item becomes more grammatical" (Hopper \& Traugott 1993:2). The only published contributions in this arena to date, using AAVE data, are those by Cukor-Avila \& Bailey 1995 and by Rickford \& Theberge-Rafal 1996; but given the evidence of ongoing grammatical change in AAVE, this theoretical area is likely to show future growth.

\section{Summary}

The African American speech community, with a linguistic repertoire which includes one of the most distinctive varieties of American English (AAVE) one which richly exemplifies processes of sociolinguistic variation and change - has played a crucial role in the development of sociolinguistic theory and methodology over the past 30 years. It has also, over the same period, fueled the careers of faculty and students alike, through the courses, term papers, conference papers, theses, dissertations, and publications which have used AAVE data and/or focused on issues in the study of AAVE.

CONTRIBUTIONS OF (SOCIO)LINGUISTICS TO THE

AFRICAN AMERICAN SPEECH COMMUNITY

What has (socio)linguistics returned to the African American speech community? In some respects, such as attempting to clarify the status of AAVE as a systematic and rule-governed system, a great deal. But overall, I do not believe sociolinguistics has done nearly enough, given that the motivation for AAVE research in the 1960s was the promise which it held out for practical applications in education and other areas. Our contributions to the African American community have been particularly limited over the past decade a period in which the African American working- and under-class has been, despite its many strengths, worse off than in the 1960 s. So we have been returning less, precisely when the community needs us more.

The primary area on which I want to focus is our contributions to the teaching of reading and the language arts at the elementary school level, but I begin by briefly mentioning a few areas in which I think the community has been under-served by us. 


\section{Induction of African American linguists into the field}

Despite more than a quarter century of concentrated work on AAVE, only a handful of African American faculty of any specialization exist in linguistics. Geoff Pullum claimed a few years ago that not a single US-born African American faculty member was employed in a Department of Linguistics anywhere in the US; and although I was upset by the claim, I couldn't challenge it. Arnetha Ball, John Baugh, Carol Blackshire-Belay, Irma Cunningham, Charles DeBose, Keith Gilyard, Lisa Green, Tometro Hopkins, Faye McNair-Knox, Marcyliena Morgan, Jerri Scott, Harry Seymour, Geneva Smitherman, Ernie Smith, Arthur Spears, Ida Stockman, Orlando Taylor, Fay Vaughn-Cooke, Tracy Weldon, Robert Williams, Selase Williams, and Toya Wyatt are all in Departments of Anthropology, Black Studies, Communication, Education, English, German, Pan-African Studies, Psychology, or Speech Pathology - although Baugh and Spears, at least, were formerly in Departments of Linguistics. On the other side of the coin, Walter Edwards, Salikoko Mufwene, Don Winford, and I are in Departments of Linguistics; but although some of us (Edwards, Mufwene, and myself) are now US citizens, we are originally from the Caribbean or Africa. The only exceptions that I know to Pullum's damning generalization are John McWhorter a 1993 Stanford graduate who joined the Departments of Linguistics and Afro-American Studies at the University of California at Berkeley in Fall 1995 - and Lisa Green - a 1993 graduate of the University of Massachusetts at Amherst who joined the Department of Linguistics at the University of Texas at Austin, also in Fall 1995. ${ }^{8}$

I hasten to add that there is nothing wrong with having African American linguists in departments other than linguistics, and much that is very right about it. Given the interdisciplinary interests of many African American linguists and the shortage of jobs in linguistics, the occupational niches provided by anthropology, Black studies, communication, education, English, speech pathology, and other departments are most welcome. But African American linguists could still be better represented on the faculty of linguistics departments than they are, and why they are not is worth consideration.

One reason is, of course, the PIPELINE problem. Data from 51 North American linguistics departments and programs, surveyed by the Linguistic Society of America's Committee on Ethnic Diversity in Linguistics (LSA/CEDL) in Fall 1995 (see Table 2), indicate that only $1.9 \%$ of all undergraduates and $2 \%$ of all graduates enrolled in linguistics programs were Black, and the percentage of Black faculty recorded by that survey was comparable. ${ }^{9} \mathrm{~A}$ recent Modern Language Association survey of $49 \mathrm{Ph}$.D. programs in linguistics similarly revealed that Blacks comprised only $1.5 \%$ ( 2 out of 131 ) of the $\mathrm{Ph} . \mathrm{D} . \mathrm{s}$ in linguistics granted to students who remained in the US after grad- 
TABLE 2. Ethnic distribution of undergraduates, graduates, and faculty in 51 US linguistics departments in Fall 1995

\begin{tabular}{llll}
\hline \hline & $\begin{array}{l}\text { Undergraduate } \\
\text { Ethnicity }\end{array}$ & $\begin{array}{l}\text { Graduate } \\
\text { Students }\end{array}$ & $\begin{array}{l}\text { Faculty } \\
\text { (in linguistics } \\
\text { departments) }\end{array}$ \\
\hline Blacks & $11(1.9 \%)$ & $23(2.2 \%)$ & $6(1.9 \%)$ \\
Native Americans & $6(1 \%)$ & $3(0.3 \%)$ & $6(1.9 \%)$ \\
Asians/Pacific Islanders & $29(4.9 \%)$ & $58(5.6 \%)$ & $10(3.2 \%)$ \\
Whites (non-Hispanic) & $467(79.6 \%)$ & $791(75.9 \%)$ & $278(88 \%)$ \\
Hispanics & $19(3.2 \%)$ & $23(2.2 \%)$ & $11(3.5 \%)$ \\
"Minority" & $22(3.7 \%)$ & - & - \\
"International" & $26(4.4 \%)$ & $138(13.2 \%)$ & $1(0.3 \%)$ \\
Other/Unknown & $7(1.2 \%)$ & $6(0.6 \%)$ & $4(1.3 \%)$ \\
Total & $587(100 \%)$ & $1,042(100 \%)$ & $316(100 \%)$ \\
\hline \hline
\end{tabular}

Source: Linguistic Society of America, Committee on Ethnic Diversity in Linguistics survey.

uation in 1993-94, while they comprised 3.3\% (30 out of 916) of corresponding Ph.D.s in English. ${ }^{10}$

But even with this limited pool, I believe that more can be done to attract African Americans into linguistics. For one thing, we are sometimes not sufficiently nurturing and encouraging to African American students and others of color who enroll in our classes. I have heard of students who were initially attracted to our field, but were discouraged by the insensitivity or impatience of the TAs and professors they encountered in linguistics; African American students and junior faculty alike could benefit from better mentoring. Moreover, some committees on admissions, appointments, and promotions in our field suffer from the institutional racism endemic in American society more generally, and they are simply not proactive enough on behalf of African Americans and other students of color when the opportunities come up. ${ }^{11}$ In a period when affirmative action is being dismantled in several states and is threatened at the national level, it will take an even greater effort than linguistics has displayed, in the 20 years since the Equal Opportunity Act of 1964, to increase the representation of African Americans and other students and faculty of color. ${ }^{12}$ Nevertheless, it is heartening that the Linguistic Society of America has finally created a Committee on Ethnic Diversity in Linguistics to address the problem. There is evidence that, with commitment and effort, progress can be made. ${ }^{13}$

Overall, sociolinguistics has done better than other fields in attracting African Americans to linguistics; e.g., many of the faculty listed in the first paragraph of this sub-section are primarily or partly in sociolinguistics. But given our debt to the community, and the valuable contributions which the handful of African American sociolinguists has already made to our field, ${ }^{14}$ we need to view the under-representation of African Americans in linguis- 
tics as an academic limitation for our field as well as a socio-political embarrassment. We also need to work with other departments more systematically, and with our university administrations and high schools, to redress the situation. ${ }^{15}$

\section{The representation of the African American speech community}

A second issue is that the representation of the African American speech community in the writings of sociolinguists, ethnographers, and folklorists has sometimes been very negative, because of the kinds of examples we have chosen to include. Geneva Smitherman-Donaldson and Marcyliena Morgan - both African American women, I should add - have spoken eloquently on this issue, as the following quotations illustrate:

Books like Abraham's Deep Down in the Jungle (1964), Jackson's Get Your Ass in the Water and Swim like Me (1974), and Folb's Running Down Some Lines (1980) - the titles themselves tell you something - conveyed the impression that black speech was the lingo of criminals, dope pushers, teenage hoodlums, and various and sundry hustlers, who spoke only in "muthafuckas" and "pussy-copping raps." Overwhelmingly, the black subjects of the research were predominantly male, and the content of their speech data primarily sexual. For example, several of the toasts in Jackson's collection were narrated by ex-convicts, and most were collected at prisons ... There is no denying that the "toast world" is a dimension of black linguistic tradition; the point, however, is that a slice of black folk character was presented as the whole. (Smitherman-Donaldson 1988:162)

With few exceptions ... research on discourse and verbal genres has highlighted male-centered activities and male sexual exploits. As a consequence, African American women are either erased from the urban landscape because of their purported linguistic conservatism or portrayed as willing interlocutors and audiences for the plethora of street hustler raps and misogynistic boasting reported by researchers. Since the speech community, in this case, is viewed as a monistic entity, a specific speech event is often presented as a generalized norm rather than characteristic of a particular style or genre. Kochman (1981:75) is emblematic of this problem with his statement, "In Black culture it is customary for Black men to approach Black women in a manner that openly expresses a sexual interest" ... Kochman contends that this form of "rapping" is a norm, though his assumptions are mainly based on male self-reporting of street culture and street observations. The fallout that results from this generalization is, once again, both the African American community's rejection of research 
on AAE and accusations from linguists of community self-hate. (Morgan 1994a:137)

The criticisms reflected in these quotations can be extended to the writings of sociolinguists on a variety of subjects that have nothing to do with speech events, but still end up with examples involving violence, obscenity, or sex. I do not believe this is because we are ourselves titillated by these materials, or seek to titillate our audiences, but rather because we are trying earnestly to demonstrate that we have overcome the "observer's paradox" discussed by W. Labov 1966, and that we have tapped into the mother lode of the "vernacular." For instance, in W. Labov \& Harris 1986, Harris' skill as an interviewer is presented in these terms:

... he never interviewed anyone until knowledge of the broader, shared background allowed him to go deeper into the emotional and sexual life than sociolinguistic interviews had gone before, and to obtain samples of emotional interchanges that reached a high pitch of intensity. (2)

Among the many recordings of the core group, none showed a greater level of intensity than a session with Jackie and her close friend "Pam." They met at Harris' house to record their denunciation of the sexual behavior of a man that they both knew. They also dealt with the fighting behavior of a number of other young men in the neighborhood ... "PAM: They ain't do shit! They ain't do shit! And from that day on we been walking up to they block, and they ain't do shit! Koko big rocks don't mean shit." ... (4)

When Rickford \& McNair-Knox 1994 was in preparation, we had to make a real effort to avoid the stereotypic examples that had gone before. Our paper still includes examples that discuss gang murders and "slamming partners" - but we excised references to "bitches" and other misogynistic posturing which we had originally included in line with sociolinguistic tradition. In the end, our examples were more representative of the RANGE of topics and interests of our speakers than they might otherwise have been. According to Morgan 1994a, members of the African American speech community have expressed concern that "the language styles purported to describe the African American community represent the entire social field" (138) and the "multi-situated nature of African American life" (139).

A final comment which can be made in this connection is that concern for the ways African Americans are portrayed in linguistics publications is paralleled by the concern which has been expressed recently about the ways that women are under-represented, or represented in terms of negative stereotypes, in the examples used in linguistics texts (Battistella 1996, Bergvall 1996, Macaulay \& Brice 1996, Moonwomon-Baird 1996). Bergvall comments that 
"the problems of under-representation and misrepresentation ..., as well as linguists' failure to acknowledge these problems, can be traced to the structuralist separation of the study of form from content or context"; this applies equally to the perpetuation of racism and sexism in linguistic examples. ${ }^{16}$

\section{Prisons, courts, and workplaces}

One area in which racial discrimination and injustice are still quite evident in American life is the disproportionate number of African Americans who are arrested, imprisoned, and executed. In 1991, African Americans constituted only $12.3 \%$ of the population nationwide, but $43.4 \%$ of the inmates in local jails, and $45.6 \%$ of the inmates in state prisons. ${ }^{17}$ In 1993, African Americans constituted about $12.5 \%$ of the national population, but $31 \%$ of all those arrested (Information Please Almanac 1996:853) and 40.8\% of prisoners under sentence of death (US 1995:220). Between 1930 and 1993, African Americans constituted $52.7 \%$ of prisoners executed under civil authority (US 1995:220). ${ }^{18}$ Late in 1995, the Sentencing Project, a national non-profit organization that deals with criminal justice issues, reported that "one in three Black men between the ages of 20 and 29 are within the grasp of the criminal justice system" (as summarized by Jones 1995:9).

Although the injustices reflected in these statistics extend far beyond linguistics, some undoubtedly include a linguistic component. Sociolinguists have shown, through their involvement in and/or their study of court cases over the past two decades (Lind \& O'Barr 1979, O'Barr 1982, J. Milroy 1984, Shuy 1986, W. Labov 1988, Dumas 1990, Rieber \& Stewart 1990), that they can make useful if not always successful contributions to the determination of innocence or guilt and other aspects of the legal process. In the case of African Americans, however, our contributions have so far been limited. Gumperz 1982a provides a discourse- and feature-based defense of a Black Panther community leader who was accused in the 1960s of threatening the life of the president, although the case itself was dismissed before it went to trial. Butters 1997 discusses his testimony on behalf of an African American man in Virginia whose lawyers attempted to appeal his conviction and death sentence on the grounds that the indicting, convicting, and sentencing processes were tainted by racial discrimination. ${ }^{19}$ But there is undoubtedly more that we can do. Matsuda 1991 and Lippi-Green 1994 have shown how accent and dialect discrimination in hiring and firing have been tolerated in US courts; the victims in their cases are mainly foreign-born immigrants, but a few are speakers of Hawaiian Pidgin English and of AAVE. Lippi-Green and her students (Arnett et al. 1994) have turned more recently to the ways in which Disney animated cartoons teach children how to discriminate against non-standard dialects from an early age. ${ }^{20}$ One is led to believe from this and other evidence that language is an element in the disproportionate number of African Americans imprisoned and executed in this country. ${ }^{21}$ 
The level of UNEMPLOYMENT among African Americans is also significantly higher than among Whites. In 1993, the unemployment rate among Whites in general was $6.0 \%$, and among Whites between the ages of 16 and 24 it was 11.3\%; for African Americans, the 1993 unemployment rates were $12.9 \%$ and $31.7 \%$, respectively, twice and nearly three times as high as the corresponding White rates. ${ }^{22}$ UNDER-employment - including employment in jobs with responsibilities and pay lower than merited by one's training or skill is somewhat harder to document, but one combined reflection of unemployment and under-employment is annual income. In 1993, the median income for all households, regardless of race, was $\$ 31,241$; the median for Whites was $\$ 32,960$, and the median for Blacks was only $\$ 19,533$ (US 1995:469). In the same year, the percentage of all US household whose earnings placed them below the poverty level was $15.1 \%$; for Whites, the figure was $12.2 \%$; for Hispanics, 30.6\%; and for Blacks, 33.1\%, or one-third (US 1995:480). As with discrimination in the judicial system, the roots of these disparities clearly extend beyond language - including "racism, inequality and cultural intolerance," issues which Roberts et al. (1992:370) felt compelled to include in their cross-cultural communication interventions in the UK. But there are also language elements to the unemployment and under-employment of African Americans (cf. Jupp et al. 1982:234), and these have not been adequately explored in American sociolinguistics.

As an example of the kinds of sociolinguistic research and intervention which could be done, we might note the work done by the Industrial Language Training (ILT) service established in the UK in 1974 to improve communications in multi-ethnic workplaces, primarily but not exclusively among immigrants for whom English is a second language. In the more than two decades of its existence, the ILT has worked with ethnic minority workers (and would-be workers) as well as with White managers, supervisors, and other staff who interact with ethnic minorities. Not only have they provided training in the mechanics of English, but they have also helped to raise sensitivity on both sides to the deeper levels of interpretation and contextualization at which problems of cross-cultural stereotyping and miscommunication are often manifested. The ILT program has benefited from the scholarship and advice of leading sociolinguists (see Gumperz et al. 1979); ${ }^{23}$ and, according to Roberts et al. (1992:385): "ILT has been a success story in a number of respects. Thousands of people in hundreds of workplaces received training in a complex field. No other public service in the field of ethnic relations has a comparable record."

In the US, little comparable work has been done on behalf of African Americans or other people of color, but what has been done indicates the need to do more. The closest parallel to ILT work is research done by Akinnaso \& Ajirotutu 1982 in Oakland in 1976, as part of a project on inter-ethnic communication supervised by John Gumperz. The authors collected data on 
the performance of 12 African American students in simulated job interviews; and in return, they took over the assessment training portion of the four-week CETA (Comprehensive Employment and Training Act) program in which these students were enrolled. Akinnaso \& Ajirotutu examine narratives told by two women in their sample, showing that one of them effectively uses rhetorical strategies and discourse structuring techniques, in order to respond to the underlying intent of the interviewer's question and present herself positively, while the other does not. As they note (143),

there is common agreement that discourse conventions are very crucial to employability ... Consequently, where several candidates have equivalent qualifications, as is often the case in present-day urban settings, candidates who can linguistically match a standard variety and interact within the discourse conventions of the standard language are normally at an advantage.

This conclusion parallels the results of a very different kind of research done by Terrell \& Terrell 1983, who sent six African American applicants out for secretarial positions at one hundred sites. Three spoke SE, and three spoke AAVE. The authors report that the SE-speaking applicants were given longer interviews, offered more jobs, and offered jobs with higher pay than the AAVE-speaking applicants. Although most sociolinguists would reject the Standard Language Ideology (Lippi-Green 1994) which lies behind results like these, one cannot reject as easily the reality of its existence. In attempting to increase employment opportunity for AAVE speakers, sociolinguists might follow the model of the ILT program in the UK, working both with employers (to modify their negative attitudes) and with AAVE-speaking jobapplicants (to increase their bidialectal competence in AAVE and SE, and their sociolinguistic switching abilities). ${ }^{24}$ We should also take caution from research by W. Labov1995, showing that the relative frequency of transcription "errors" in SE usage made by an African American word-processor in Chicago (Andrea Ellington) did not correspond to the relative frequency of corresponding features in AAVE. ${ }^{25}$ Although plural $s$-absence is low in most AAVE studies, and verbal $-s$ absence high, Andrea had more difficulties with SE plural marking (errors $53 \%$ of the time) than with verbal $-s$ (errors only $13 \%$ of the time). Moreover, it was the absolute rather than relative frequency of her "errors" that affected her boss' evaluation. These findings suggest that we will need to study how AAVE-speaking employees actually perform on the job, rather than predicting such performance on the basis of linguistic regularities uncovered in the existing sociolinguistic literature.

\section{Elementary education}

The applied area in which sociolinguistics most self-consciously set out to make a contribution is of course in elementary education, especially in the curriculum-central areas of reading, writing, and the language arts. I think 
table 3. California Assessment Program scores (1989-90) for Palo Alto and Ravenswood (including East Palo Alto) School Districts, San Francisco Bay Area, CA

\begin{tabular}{|c|c|c|c|c|c|c|c|c|c|}
\hline \multirow[b]{2}{*}{ District } & \multirow{2}{*}{$\begin{array}{l}\text { Subject } \\
\text { Grade }\end{array}$} & \multicolumn{3}{|c|}{ Reading } & \multicolumn{2}{|c|}{ Writing } & \multicolumn{3}{|c|}{ Math } \\
\hline & & 3 & 6 & 8 & 3 & 6 & 3 & 6 & 8 \\
\hline $\begin{array}{l}\text { Palo Alto } \\
\text { State rank (percentile) }\end{array}$ & & $\begin{array}{l}337 \\
96\end{array}$ & $\begin{array}{l}339 \\
99\end{array}$ & $\begin{array}{l}361 \\
98\end{array}$ & $\begin{array}{l}329 \\
94\end{array}$ & $\begin{array}{l}335 \\
99\end{array}$ & $\begin{array}{l}343 \\
97\end{array}$ & $\begin{array}{l}348 \\
99\end{array}$ & $\begin{array}{l}386 \\
99\end{array}$ \\
\hline $\begin{array}{l}\text { Ravenswood } \\
\text { State rank (percentile) }\end{array}$ & & $\begin{array}{l}237 \\
16\end{array}$ & $\begin{array}{l}215 \\
3\end{array}$ & $\begin{array}{l}186 \\
2\end{array}$ & $\begin{array}{l}246 \\
21\end{array}$ & $\begin{array}{l}231 \\
3\end{array}$ & $\begin{array}{l}237 \\
1\end{array}$ & $\begin{array}{l}230 \\
3\end{array}$ & $\begin{array}{l}192 \\
1\end{array}$ \\
\hline
\end{tabular}

we can claim to have done some useful things here, certainly more than any other field of linguistics. This is particularly true in the aftermath of the Dec. 18,1996 , decision by the Oakland School Board to recognize the "Ebonics" or AAVE of their African American students in teaching them Standard English. At the general meeting of the Linguistic Society of America in Chicago on Jan. 3, 1997, members unanimously approved supporting the Oakland decision; and linguists of all theoretical persuasions, especially sociolinguists, have since then spoken out repeatedly in the media, attempting to quell the massive public opposition to and misunderstanding of the Oakland proposal.

Despite this most encouraging recent involvement in a vital educational issue, it must still be said that, on balance, we have not done enough, particularly over the past decade - a period in which the educational prospects of lower- and working-class African Americans have, if anything, grown worse. W. Labov et al. (1968:1) reported that the African American peergroup members they studied in Harlem were perhaps "three, four, or five years behind grade level" in reading. I don't know what the current statistics are for New York, but I doubt that they have improved. In East Palo Alto, my own research base - third-graders in the primarily African American Ravenswood School District - scored at the 16th percentile statewide on the reading component of the California Assessment Program in 1989-90; by the sixth grade they had gotten even worse, scoring at only the 3rd percentile (see Table 3). By contrast, third and sixth graders in Palo Alto School District, adjoining but primarily White, scored at the 96th and 99th percentiles, respectively (Peninsula Times Tribune, Nov. 8, 1990). More recent tests, e.g. the experimental 1993 California Learning Assessment Program (CLAS), continue to document similar disparities (San Jose Mercury News, March 9, 1994, p. 12A). It is perhaps not surprising that, when the elementary school products of East Palo Alto are thrown together with the products of Palo Alto and other peninsula cities in high school, they drop out at an alarmingly 
high rate, reportedly as high as $70 \%$. It may be inevitable that, when education fails them, such students are left with few marketable skills, and get drawn into lives of drugs and crime. East Palo Alto has become a major drug procurement area on the San Francisco peninsula, and the city had a higher per capita rate of homicides in 1992 than any other city in the nation, including Chicago, Detroit, and New York. That rate has since been reduced, but the overall quality of education and life in the city has not improved significantly.

Data from other cities reveal the same grim picture. Michael Casserly, Executive Director of the Council of the Great City Schools (comprising 50 of the nation's largest urban school districts), testified on this topic before a US Senate Appropriations Subcommittee on January 23, 1997. He stated that, in 1994, Black students 9 years old were 29 points behind their White counterparts; but by age 13 , they were 31 points behind, and by age 17 they were 37 points behind (data source: National Assessment of Educational Progress).

What has sociolinguistics said or done about the educational roots of these problems? Through descriptive work funded initially by the Office of Education (see W. Labov et al. 1968:ii, Wolfram 1969:ix), we have demonstrated the systematicity of AAVE, and have shown how it varies by social class and style. We have rebutted (W. Labov 1970, Baugh 1988) the misconceptions about the cognitive limitations of AAVE use suggested by non-linguists like Bereiter \& Engelmann 1966 and Farrell 1983. We have also made valuable contributions to changing the perceptions of educators, speech pathologists, and students about AAVE as deficit rather than difference - with the positive effects of these efforts reflected in the position statements on social dialects articulated by the Conference on College Composition and Communication (CCCC) in 1974, ${ }^{26}$ and by the American Speech-Language-Hearing Association (ASHA 1983), ${ }^{27}$ in experimental language awareness curricula (Adger et al. 1992, Wolfram 1993), and in handbooks for speech pathologists and teachers (Taylor 1986, Baltimore 1993). However, the wave of negativity elicited by the Oakland Ebonics proposal of December 1996 shows that we need to keep up this educational effort.

We have noted the unfair disadvantages which IQ tests often pose for AAVE speakers (W. Labov 1976, Wolfram 1976, 1986, 1991:228-49, Smitherman 1986:237-41, Hoover et al. 1987, Taylor \& Lee 1987). We have considered, particularly in the late 1960 s and early 1970 s, how dialect readers, drills, and other innovative methods might be used to improve the teaching of READING to African American children (Baratz \& Shuy 1969, Fasold \& Shuy 1970, W. Labov 1970, Burling 1973, DeStephano 1973, Simpkins \& Simpkins 1981, Starks 1983, Brooks 1985). In the Ann Arbor Black English trial of 1979, we made substantial contributions (Smitherman 1981b, W. Labov 1982, J. W. Chambers 1983) to Justice Joiner's ruling that the School Board 
had failed to take appropriate measures to overcome the barriers to equal education posed by the language of the African American children who were faring badly at the Martin Luther King Jr. elementary school (more specifically, teachers' negative attitudes toward their AAVE speech). Later on, we drew attention to the "topic associating" style of oral narration used by some African American schoolchildren, and the ways in which they were disfavored by teachers who preferred a "topic centered" style (Michaels 1981, Taylor \& Matsuda 1988). We have also recommended, more recently, that African American rhetorical and expressive styles should be more fully accepted and exploited in the classroom (M. Foster 1989, Hoover 1991, Ball 1992, Smitherman 1994); and that the linguistic needs of students who are native speakers of non-standard English should be considered by policymakers in allocating federal and local funding for education (Baugh 1997). These are all valuable accomplishments, ${ }^{28}$ especially when compared with the little we have accomplished on legal and workplace issues, and with the even less which our colleagues in other areas of linguistics have contributed. But because our research involvement and interest in African American education have not been sustained - and because we have generally not stayed in touch with students, their teachers, and their communities - what we have accomplished in the schools falls short of what we might have been able to do, and still can do, in this area.

Take for instance the issue of "dialect readers" as a preliminary aid in teaching reading to speakers of AAVE. The case for them was first made by Stewart 1969, who argued that, for AAVE speakers (as for speakers of West African languages learning to read in English or French), it was pedagogically useful to separate the task of learning to read from that of learning a second language or dialect. In support of his proposal that students first learn to read in their native dialect, and then transfer those skills to reading in a standard variety, Stewart (170) cited experimental research in Swedish by Österberg 1961: "In a Swedish-dialect context, Tore Österberg found that the teaching of basic reading skills in the non-standard dialect of the school children in a particular district (Pitea) increased proficiency, not only in beginning reading in the nonstandard dialect, but also in later reading of the standard language."

Other linguists who contributed to the edited collection in which Stewart's article appeared (Baratz \& Shuy 1969) agreed on the general value of dialect readers, and focused on implementation issues like what orthography to use and how to handle the transition from SE. By the 1970s there were two or three sets of pilot textbooks in AAVE, including the ambitious Bridge reading program developed for Houghton Mifflin by Simpkins et al. 1977. The Bridge materials included texts and exercises written in three varieties: AAVE, a transitional variety, and Standard English (SE). Here is an example of the 
opening paragraphs from the AAVE and SE versions of one of their stories,

"A friend in need":

No matter what neighborhood you be in - Black, White or whatever young dudes be havin they wheels. Got to have them. Well, anyway, there happen to be a young brother by name of Russell. He had his wheels. Soul neighborhood, you know. He had this old '57 Ford. You know how brothers be with they wheels. They definitely be keeping them looking clean, clean, clean.

Young guys, Black or White, love their cars. They must have a car, no matter how old it is. James Russell was a young man who loved his car like a baby loves milk. He had an old blue and white ' 59 Chevrolet. $\mathrm{He}$ spent a great deal of time keeping his car clean. He was always washing and waxing it.

The Bridge stories were followed by comprehension and other skill exercises, and they were introduced by a recording of a young man speaking to the kids in the vernacular:

What's happenin', brothers and sisters? I want to tell you about this here program called Bridge, a cross-cultural reading program. Now I kNOw what you thinkin'. This is just another one of them jive reading programs, and that I won't be needin' no readin' program. But dig it. This here reading program is really kinda different. It was done by a brother and two sisters, soul folk, you know ...

Simpkins \& Simpkins (1981:237), reporting on their experimental use of the Bridge program with 417 seventh- to twelfth-grade students across the US, noted that they showed "significantly larger gains" on the Iowa Test of Basic Skills in Reading Comprehension than the control group of 123 students who were taught with their "regularly scheduled remedial reading instructional activities." In particular (238),

For grades $7-12$, the average gain in grade equivalent scores for the group using Bridge was 6.2 months for four months of instruction compared to only an average of 1.6 months of instruction for students in their regular scheduled classroom reading activities. The group using Bridge exceeded the normative level (four months gain for four months of instruction), many of them for the first time in their academic careers. [Emphasis in original.]

However, despite these experimental plusses in its favor, the program did not survive. According to Gary Simpkins (p.c.), the publishers were upset by the fact that they were losing money and by the fact that the program was crit- 
icized by columnists and educators. Critics of the Bridge approach apparently included African-American educators and community leaders, as had also been the case with earlier attempts to incorporate dialect readers in Washington, DC, and to take AAVE into account in addressing the language arts needs of AAVE-speaking children more generally (Stewart 1975). ${ }^{29}$ This was also true in 1996, with African American leaders like Maya Angelou and Kweisi Mfume among the harshest critics of the Oakland resolution (although they mistakenly thought that the aim was to teach Ebonics and not standard English).

Partly because of the demise of Bridge, sociolinguists writing in the $1980 \mathrm{~s}$ and 1990s (e.g. Baugh 1981:25, Wolfram 1991:255-56, Wardhaugh 1992:340) have almost uniformly rejected the idea of dialect readers (exceptions are W. Labov 1994, Rickford \& Rickford 1995). But they have done so with little or no regard to the experimental evidence that dialect readers do in fact HELP to teach AAVE-speaking children to read - and without scrutinizing the attitudinal barriers to their use, or asking how they might be overcome.

With respect to the EXPERIMENTAL evidence (in addition to the positive results reported by Simpkins \& Simpkins 1981), Leaverton 1973 reported the use of an everyday (AAVE) and school talk (SE) version of four stories with 37 students in an elementary school in Chicago. He found that students in the experimental group, exposed to both the everyday talk and school talk versions, made more progress in learning to read than those in the control group, exposed only to the school talk version. Hall et al. 1979 also tested 16 African American and 16 White children in Head Start programs in New York City, and found that the African-American children did considerably better on a story recall task when the story was presented in AAVE. Robert Williams, who originally created the term Ebonics in 1973 as a replacement for pejorative terms like "broken" and "non-standard" English, also reported in a 1975 article (Williams \& Rivers 1975:104-5) that 900 Black children who were tested (Kindergarten, first and second grades) did considerably better on an Ebonics version of the Boehm Test of Basic Concepts than they did on the original standard English version. Moreover, when four students in my "African American Vernacular English" course (Maroney et al. 1994) tested the response of 20 junior high school students in East Palo Alto to dialect and standard version of the Bridge stories, they found that the students preferred the AAVE stories and did considerably better on stories written in the dialect (see Figure 1): "Although the students were able to understand concepts from both stories, there was a higher frequency of correct answers for the AAVE versions of the stories: Dreamy Mae - $95.8 \%$ correct in AAVE, versus $79.2 \%$ in SE; A Friend in Need - $93.8 \%$ correct in AAVE, versus $71.9 \%$ in SE."

When my wife, Angela, and I attempted to replicate the experiment of Maroney et al. in an East Palo Alto elementary school where we had been 


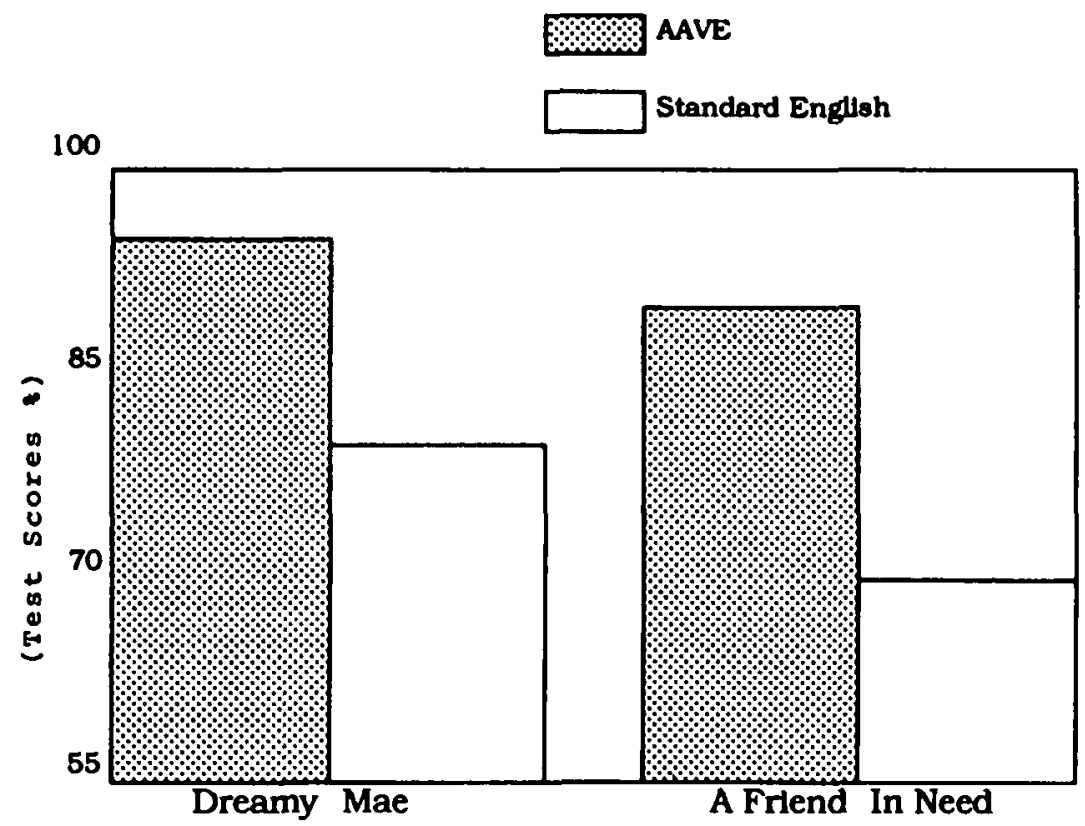

FIGURE 1: Percentage of correct responses on comprehension tests, according to variety used - AAVE vs. SE. (Source: Rickford \& Rickford 1995:119, based on Maroney et al. 1994:21.)

volunteering on a regular basis, we found, contrariwise, that comprehension was better with the SE stories than with the AAVE ones. ${ }^{30}$ However, there are explanations for the differences between our results, including the possibility that students may have felt more tired and spent less time on the AAVE versions because they always came after the SE versions (Rickford \& Rickford 1995:120). In the face of the largely positive experimental results which dialect readers have yielded to date, we need to continue to experiment with their use in classrooms with substantial AAVE-speaking populations.

With respect to ATTITUDEs, it is worth noting that attitudes toward AAVE are more positive now among working-class adolescents and young adults than they seem to have been two or three decades ago (Hoover 1978, Fordham \& Ogbu 1986); youths and their parents may now be more open to experimenting with dialect readers. Angela Rickford (1996:47, 127), using African American folktales and narratives with students in an East Palo Alto school more recently, has found that teachers and students were very positive about the use of AAVE in dialog. Not all teachers, students, or parents will feel similarly, and some may balk at the extension of AAVE outside of dialog; but to the extent that dialect readers can be shown to increase inter- 
est and comprehension and yield positive results, more and more teachers are likely to be willing to experiment with them. Specific suggestions for how sociolinguists might provide leadership in the experimental use of dialect readers are provided by Rickford \& Rickford 1995, who note in closing (12122) that "The idea is not to resurrect the issue of dialect readers as a panacea, but to consider it as one of several possibilities to which sociolinguists should contribute research time and effort as we become involved once more with educational and other applied issues."

\section{WHAT CAN WE DO?}

My proposal is not that we sTop drawing on data from the African American speech community: we need the data for our theory and methodology, and our basic research can fruitfully feed back into the needs of the community. But we should start giving back MORE, and training our students to give back more, following the "principle of the debt incurred" which W. Labov (1982:173) adumbrated: "An investigator who has obtained linguistic data from members of a speech community has an obligation to use the knowledge based on that data for the benefit of the community, when it has need of it." Perhaps as a start we might demand from ourselves and our students one hour of community service or applied work for every hour of tape collected, or every hour spent on theoretical and descriptive issues. There are two different kinds of activities in which we can get involved:

(a) Activities that draw on our expertise and involvement as linguists, including (but not limited to) the ones suggested in this article: training and employing more African American linguists, representing the community positively in our writings, contributing to the solution of legal and employment issues facing the community, getting involved in classrooms with African American students, and doing research on better ways of teaching reading and the language arts at the elementary, secondary, and adult education levels. ${ }^{31}$

(b) Activities that bear little or no direct relation to linguistics, such as tutoring in math, working in soup kitchens, initiating a book drive for a prison or community center, getting involved in building or renovation projects, applying for grants on behalf of community agencies, and helping teenagers to fill out college applications.

Obviously, as a linguist, I believe that the former activities are potentially more important: they draw more uniquely on our expertise, and offer more opportunities for feedback into theory and description. But the latter are relevant, too, and I would rather see us do something than nothing, establishing firmly for ourselves and our students the notion of "service in return." In relation to the former, there are certainly models, both within sociolin- 
guistics and other fields, of what we might do. I would like to close this article by pointing to some of the proactive initiatives which have already been started, and by indicating some ways in which we might do more.

One concept which has been gaining momentum in higher education, but has barely touched linguistics, is the concept of SERVICE LEARNING - which, when integrated into the academic curriculum, links students' involvement in community service with their academic learning. Like courses in a number of fields at Stanford, my "Introduction to sociolinguistics" and "African American Vernacular English" courses include an optional community service component for an extra unit of credit. Students who take the option engage in community service related to the content of the course, e.g. as language arts tutors in East Palo Alto elementary schools, or as instructors in English as a second language to food service and other immigrant workers on campus. The students meet in a weekly section with a teaching assistant to share their service experiences and ideas, and to relate what they're doing in the community to what they're learning in the classroom. They are required to submit a paper at the end of the quarter reflecting on their experience, and explicitly exploring ways in which their learning about social dialects, multilingualism, and other topics has contributed to their service within the community, and vice versa.

Although a number of American universities (including Cornell, Indiana, Stanford, and Vanderbilt) have been active in the service learning "movement," the University of Michigan's Office of Community Service Learning (OCSL) is the front-runner in this type of education. The OCSL Press has published two edited collections on the topic, PRAXIS I and II (Howard 1993b, Galura et al. 1993), and they also produce a periodical, the Michigan Journal of Community Service Learning. Jeffrey Howard, the OCSL director, has written an article (Howard 1993a) setting out 10 "principles of good practice in service learning pedagogy," and linguists interested in establishing service learning in their courses might find it useful to consider them. ${ }^{32}$ The principles of Howard's which I have found most helpful are these (Howard 1993b:5-8):

1. Academic credit is for learning, not service.

2. Do not compromise academic rigor.

5. Provide educationally sound mechanisms to harvest the community learning.

7. Minimize the distinction between the student's community learning role and the classroom learning role.

Within linguistics, the early works of Baratz \& Shuy 1969, Fasold \& Shuy 1970 , and W. Labov 1970 were helpful to teachers, I think; and they would be even today, were it not for their anachronistic language ("Negro Non Standard") and the fact that they do not incorporate research findings of the 
past quarter century. Fries 1962 was, in my opinion, a remarkable attempt to "bring to the study of the problems of learning to read and of the teaching of reading ... the knowledge concerning human language which linguistic science has achieved" (vii-viii). One of the things which Fries' book makes clear - as does our involvement in the schools locally - is that we can't just jump in with the expertise of our own discipline: we have to read the literature on the teaching of reading, to learn about phonics, comprehension testing, the psychology of learning, and so on (cf. Rouch \& Birr 1984). The panel on "Linguistics in the schools," which Mark Aronoff organized at the 1994 LSA meeting, was a good indication that others feel the need for us to get involved; but I was struck by how much more the participants needed to learn from the discipline of education, and from the schoolteachers and students with whom we have to work.

Another indication of recent interest in the applications of linguistics research is the 1eport of Wolfram \& Schilling-Estes 1995b on the deliberations of the linguists who met in September 1995 to identify ways in which linguistics could contribute to the Human Capital Initiative (HCI) launched by the National Science Foundation in 1994. Although brief, this document identifies several research questions which linguists could pursue to contribute to the six foci of the HCI: fostering successful families, building strong neighborhoods, educating for the future, employing a productive workforce, reducing disadvantage in a diverse society, and overcoming poverty and deprivation. The Center for Applied Linguistics (CAL) has of course been involved in some of these areas since its founding in 1959, and some of the applied work relating to AAVE cited in this article (e.g. Baratz \& Shuy 1969, Fasold \& Shuy 1970) was published under its auspices. More recently it has focused heavily on literacy for adults learning English as a second language, and on the linguistic challenges of US immigrants.

On a different sort of applied tack, the 1995 LSA meeting included papers by Craig 1995 and by Wolfram \& Schilling-Estes 1995a, documenting "language preservation" efforts which they are carrying out on behalf of two widely separate communities, at their request - the speakers of the Rama language in Nicaragua and of the Ocracoke dialect in North Carolina, respectively. Wolfram and Schilling-Estes and their colleagues, working with the Ocracoke Historical Preservation Society, have created several products to document and preserve the island's dialect, including an audiotape of speech samples, a video documentary, a dialect lexicon, and a dialect awareness curriculum for schoolchildren. Craig has shared with me copies of the "Illustrated dictionary in Rama" and other materials which she and her students have prepared for use by Miss Nora and Mr. Ortiz, local Rama speakers, in Nicaraguan classrooms. She has also shared with me her paper on ethical issues of fieldwork (Craig 1992), which includes a 17-point list of ethical and 
empowerment issues for fieldworkers. From them I mention only these two: the importance of "producing materials of use to the community" (no. 14) and the importance of "following up, staying in touch" after one's data are collected (no. 15).

Linguists working on Native American languages have also provided a model of how theoretical and descriptive linguistic research can be used to serve community needs, e.g. in the preparation of dictionaries and language learning materials. Hinton 1994 discusses some of the challenges and pleasures of collaboration between linguists and Native American communities, and lists some of the linguists and projects that have been active in California since the 1970s. Among the many sections of her article from which students of AAVE interested in applications might draw inspiration is this one:

One reason that so many linguists are interested in doing work of the sort that language communities want done is because, despite the professional conflicts, this work is so fulfilling. All of us want to do something meaningful with our lives. ... My experience and feelings [working with the Havasupai and Hualapai communities in Arizona] are probably very close to those of other linguists who have been honored to apply their skills to community needs: the opportunity to be in the language communities, to develop and maintain ties to the people there, and to do something of use gives great personal joy. (253-54)

Nora England, a linguist in the Anthropology Department at the University of lowa, has worked on Mam, a Mayan language; she has also done important work in training Guatemalan Mayans to be linguists. Akira Yamamoto, of the Anthropology Department at the University of Kansas, is one of the many students of American Indian languages who are involved with community concerns.

A final springboard for sociolinguists contemplating ways to return more to the community is the discussion by Cameron et al. 1992, on "whether and how research could be used to the benefit of both researcher and researched" (1). The authors suggest that researchers should not only be committed to ETHICs ("research on") but also, where possible and appropriate, to ADVOCACY ("research on and for") and EMPOWERMENT ("research on, for and with," 22). Cameron's account (1992) of her own involvement with an Afro-Caribbean youth club in London is particularly relevant because it deals with some of the issues addressed in this article, ${ }^{33}$ and because it is a good example of empowering research, in which Cameron helped the youths to do what THEY wanted - to make a video dealing with racist language and attitudes toward British Black English. Reflecting on her experience (128), she formulated the following guidelines for her own work, which we may want to adopt more generally: 
1. Ask questions that interest the researched group or are generated by them.

2. Be open about your agenda and negotiate at all stages.

3. Make the knowledge and perceptions of the researched group count; do not impose an "expert" framework unthinkingly.

4. On the other hand, share information and analytic tools; the group may reject them but it is wrong to assume from the outset they do not want to know.

5. Present what you learn from research in such a way that the researched group will find it accessible.

Note that these guidelines diverge from both theory and practice within quantitative sociolinguistics; thus guideline 2 advocates more openness about our linguistic interests rather than less (the usual response to the "observer's paradox"). But I believe that adopting them would be beneficial for sociolinguistic theory and application alike. ${ }^{34}$

The fundamental rationale for getting involved in application, advocacy, and empowerment is that we owe it to the people whose data fuel our theories and descriptions; but these are good things for us to do even if we don't deal directly with native speakers and communities, and enacting them may help us to respond to the interests of our students and to the needs of our field. Over the years, many of my students, at both the undergraduate and graduate levels, have asked poignantly how they can use linguistics to improve people's lives. I suggest that there are potential uses of this kind, but not ones which we have explored fully enough. With respect to the needs of our field, it is clear that there will simply not be enough jobs in academia for our graduates; university administrations, politicians, and the general public will increasingly ask us to justify their support in terms of the practical good we can offer in return. Increased attention to the kinds of applications I sketch in this article can help us to respond to these needs; and while this will take time, it need not be antithetical to the theoretical and descriptive research in which we are already engaged, but can complement and bolster it. It is also worth noting that the unequal partnership between sociolinguistics and the African American speech community, as documented in this article, represents a far more general problem between linguistics and the communities of speakers whose data fuel our descriptive grammars, theories, and careers. Sociolinguistics is actually less culpable in this respect than other fields, and the need for increased attention to payback and practical application should be recognized and responded to in linguistics as a whole.

\section{NOTES}

* This is a revised version of a paper which I presented in 1994 and 1995 under the title "Sociolinguistic theory and application within the African American speech community," at the 
Stanford University Linguistics Colloquium, at New York University, and at the conference on African American Vernacular English at Amherst. The lead paper which I presented at the "Service in Return" colloquium at the 1997 annual meeting of the Linguistic Society of America also drew substantially on this article. I am grateful for the comments received from the audiences at those presentations; to Angela Rickford for feedback and encouragement during the writing of this article; and to Bill Bright, Marcyliena Morgan, and Walt Wolfram for their valuable contributions.

' This is not to say that I have been entirely uninvolved in the applied and service arenas. In Guyana, I participated in workshops dealing with language arts problems, and co-authored a paper dealing with creole interference in English language writing (Rickford \& Greaves 1978). My sociolinguistic research on the South Carolina Sea Islands in the 1970s was done through the University of California at Santa Cruz's Cowell extramural and community service program, which required that community service be primary; in addition to performing a variety of other jobs, I served as classroom aide to Mrs. Johnson and Pat Conroy in the two-room schoolhouse made famous by Conroy's 1972 book. In California, I have worked as a classroom volunteer in East Palo Alto, and co-authored a paper on dialect readers in education (Rickford \& Rickford 1995), using experimental data collected in the school. In various courses on sociolinguistics or AAVE, I have also included a public service option or requirement; typically students tutor in neighboring schools or teach in adult literacy programs, exploring explicitly the connections between what they learn in the course and the language-related problems they encounter in the community.

${ }^{2}$ It is the only sociolinguistics sub-field, for instance, with an annual conference of its own, entitled New Ways of Analyzing Variation (NWAV); and it boasts its own journal, Language Variation and Change.

${ }^{3}$ Labov et al. 1968 was preceded by another report, Labov et al. 1965. Labov 1972 is based on Labov et al. 1968, which is more comprehensive and detailed.

${ }^{4}$ Baugh 1987 discusses the role which copula analysis played in the development of variable rules and other aspects of sociolinguistic theory.

${ }^{5}$ This rule covers only the deletion of the final consonant [z] in is after the vowel has been removed by contraction. It states that the copula is most likely to be absent when is is preceded by a pronoun or an NP ending in a consonant, and when it is followed by a future verb, as in He $\emptyset$ gon try to get up (12-year-old, Thunderbirds).

${ }^{6}$ One could fault Wolfram and his colleagues, like Labov and his colleagues, for relying on functionalist or consensus approaches to the analysis of class in the African American community, rather than on the conflict models which are more common in sociology (Kerbo 1983). But this is a very general weakness of the early sociolinguistics studies, as pointed out by Rickford 1986, Williams 1992, and Milroy \& Milroy 1992.

${ }^{7}$ Some phonological variables like $t h$-stopping also showed sharp stratification, while absence of plural $-s$, a grammatical variable, showed gradient stratification. But in general, the correlation of gradient stratification with phonological variation and of sharp stratification with grammatical variation was maintained:

$\begin{array}{lrrrr}\text { Voiceless } t h[\theta] \rightarrow f, t \text {, or } \theta \text { (Wolfram 1969:84) } & 71 \% & 59 \% & 17 \% & 12 \% \\ \text { Absence of possessive }-s(1969: 141) & 27 \% & 25 \% & 6 \% & 0 \% \\ \text { Absence of plural }-s(1969: 143) & 6 \% & 4 \% & 1 \% & 0 \%\end{array}$

${ }^{8}$ The names listed in this paragraph do not represent a complete listing of African American faculty in language-related departments in US colleges and universities - there are certainly others (including the contributors to Brooks 1985), and I apologize for their omission - but the general point remains valid that Blacks are under-represented on the faculties of linguistics and related departments.

${ }^{9}$ For the sake of simplicity, Table 2 ignores distinctions between US-born citizens, US naturalized citizens, and permanent US residents in each ethnic subcategory which are available in the LSA/CEDL data. However, I should note that, of the six Black faculty in linguistics, three were UŜ́-born and three were permanent residents, while all of the Black graduate students and all but one of the Black undergraduate students were US-born. I am grateful to Grant Goodall of CEDL, and to the staff of the LSA Secretariat (especially Margaret Reynolds, Executive Director), for making these data available. 
${ }^{10}$ Percentages of Black Ph.D.s reported by the MLA for Comparative Literature and Foreign Languages were 1.5\% (2/131) and 2.5\% (15/594). Data are from Table 4 of an MLA document (no author or date) entitled, "The MLA's 1993-94 survey of PhD placement: The latest linguistics findings and trends through time."

${ }^{11}$ Another barrier, discussed by Walters (1995:21), is the fact that "linguistics as it constitutes itself - in its practices, in its textbooks, and in its actions - may well be either irrelevant or insufficient to the concerns of African-American scholars," leading them to pursue languagerelated interests in other fields.

${ }^{12}$ Ethnic preferences have already been outlawed at all nine campuses of the University of California; and Proposition 209, the mislabeled "California Civil Rights Initiative" (read: "California Civil Wrongs Initiative"), which was approved by California voters in 1996, is designed to dismantle affirmative action in California more generally. According to Morganthau \& Carroll (1996:55), UC regent and CCRI supporter Ward Connerly "admits that ending racial preferences will probably lead to a 'precipitous' drop in Black enrollment within the UC system" (already only $4 \%$ Black).

${ }^{13}$ Departments of Linguistics which have managed to admit and graduate better than average numbers of African American graduate students in recent years include Stanford, the University of Pennsylvania, and the University of Massachusetts at Amherst. Except in the last case, the African-American graduate students at these universities have all specialized in sociolinguistics and/or pidgin-creole studies.

${ }^{14}$ According to W. Labov (1982:165), "The entrance of black linguists into the field was a critical factor in the further development of the creole hypothesis and the recognition of the distinctive features of the tense and aspect system [of AAVE]."

${ }^{15}$ Some universities are members of consortia which provide departments with lists of available students of color nationwide; and some provide special funds for supporting graduate students of color, and/or for helping them to visit departments once they are admitted.

${ }^{16}$ See Walters 1995 for a different critique of the representation of AAVE in introductory linguistics texts. One of his main points is that, by treating AAVE as a special case in a discussion which otherwise refers to "English" (unqualified), introductory texts fail to challenge students to see themselves as speakers of dialects which vary by ethnicity, class, region, sex, etc.; and they fail to get White students "to question their own sense of entitlement or privilege, to remind them that the standard itself is always and only an idealization" (15).

${ }^{17}$ General population data are from US 1995 , Table no. 18, p. 18. Jail and state prison data are from Smith \& Johns 1995, Table 146, pp. 104-5, and Table 162, p. 119, drawing on US Bureau of Justice statistics. A jail is defined as "a confinement facility administered by a local government agency that holds persons pending adjudication and persons committed after adjudication, usually for sentences of a year or less" (Smith \& Johns, 105).

${ }^{18}$ These figures are worse $(48.7 \%$ to $60.8 \%$ ) for the decades between 1930 and 1967 , and "better" ( $40.8 \%$ and $36.8 \%$, respectively) for the 1980s and 1990s. The former period includes a whoppingly disproportionate rate $(89 \%=405 / 455)$ of African-American executions for rape.

${ }^{19} \mathrm{~W}$. Labov 1988 discusses two other legal cases in which he and his colleagues intervened on behalf of African American workers (in 1976) and welfare recipients (in 1982).

${ }^{20}$ The "cold-hearted" black crows who jeer the hero in Dumbo, for instance, speak a marked variety of AAVE which includes done, be done, ain't for "isn't," don't for "doesn't," multiple negation, and non-agreement in present tense verbs, as well as phonological features like monophthongization ("Well, hush $m a h$ feet") and $a$ before vowels ("a elephant"). The evil hyenas in The Lion King also speak a variety of AAVE, but one marked more by lexical and phonological features than grammatical features.

${ }^{21}$ One case with an African-American defendant in which the technical expertise of a linguist might have proven useful is the recent "unjust conviction of Chester Schimberg" as reported by Attorney James Sterling Lawrence on "The Injustice Line" Web site (http://home.earthlink.net/ $\sim$ ynot/Schimber.html). Although Schimberg was convicted of rape and sentenced to life imprisonment, the victim said that her attacker, whom she could not see clearly, had a southern accent. Schimberg grew up in the north and apparently does not have a southern accent. According to Lawrence (p. 1), "The lawyer never brought out to the jury that she told police the man had a southern accent." Moreover, although the prosecutor claimed that "a person could fake a southern accent, so the failure of the attorney to bring out the fact of Schimberg's accent and heri- 
tage was harmless" (Lawrence, $p$ 2), this claim might have been invalıdated by the evidence of recent research showing clear limits on the normal ability of individuals to disguise their voices and/or Imitate other accents (Ash 1988, Butters et al 1993)

${ }^{22}$ Data are from US 1995, Tables 628 (p 400) and 635 (p 404)

${ }^{23}$ The Crosstalk film referred to by Gumperz et al 1979 is avallable from David Thomas Films Inc, 1144 Wilmott Avenue, Chicago, IL 60091 (phone 312-256-4730)

${ }^{24}$ But see Sledd 1969 for objections to promoting this kind of bidialectalısm, on the grounds that it gives comfort to the language discriminators and the supporters of White supremacy

${ }^{25}$ For Labov's general comments on Andrea's word-processing errors which are attributable to influence from AAVE, see Duneier 1994

${ }^{26}$ The Executive Committee of the CCCC, a subdivision of the National Council of Teachers of English, passed a resolution in 1972 reversing the centuries-old tradition in which teachers actively attempted to suppress non-standard dialects The resolution, affirming "the students' right to their own patterns and varieties of language" and suggesting "that teachers must have the experiences and training that will enable them to respect diversity and uphold the right of students to their own language," was approved by the membership of the CCCC in 1974 For a substantial extract of this resolution, see CCCC 1978 For a copy of the Linguistic Society of America's 1997 resolution on Ebonics, see the following website http // www leland stanford edu/ rickford/

${ }^{27}$ See also Cole 1983 and Vaughn Cooke 1983

${ }^{28}$ For a more comprehensive hist of research on AAVE and education, see Harris et al 1995, and the two-part special issue of Linguistics and Education (vol 7, numbers 1-2), ed by Tempil Champion and David Bloome, in which it appears

${ }^{29}$ But see the contributions in Brooks 1985 for broad support from African-American in guists and educators for recognition of AAVE and systematic attention to it in educational reform

${ }^{30}$ The comprehension edge was slight for "Dreamy Mae" - 70\% (42/60) correct in AAVE vs $76 \%(76 / 100)$ in SE, but it was substantial for "A friend in need" - $463 \%(37 / 80)$ correct in AAVE vs $90 \%(45 / 50)$ in SE

${ }^{31}$ These remarks apply similarly to any other populations with whom we happen to work

${ }^{32}$ See also Honnet \& Poulsen 1989, which gives several examples for each of its 10 "prunclples of good practuce for combining service and learning" (1)

${ }^{33}$ For example, negative attıtudes toward the youths' Britısh Black English, which Cameron counteracted by telling the youths about the history of pidgins and creoles, the principle of linguistic equality, and the sources of the linguistic prejudice they had encountered

${ }^{34}$ While I am sympathetic to the guidelines of Cameron 1992, I am less persuaded by Rampton's critical comparison (1992) of variationist sociolinguistics and the ethnography of communication, and his conclusion that the latter is intrinsically far more suitable for empowering research

\section{REFERENCES}

Abrahams, Roger D (1964) Deep down in the jungle Hatboro, PA Folklore Associates

Adger, Carolyn, et al (1992) Enhancing delivery of services to Black special education students from non-Standard English backgrounds (Cooperative agreement HO23400008-92) Washington, DC Office of Special Education Programs

Akınnaso, F Niyl, and Ajırotutu, Cheryl Seabrook (1982) Performance and ethnic style in job interviews In Gumperz 1982b 119-44

Arnett, Carlee, et al (1994) Teaching chıldren how to discrimınate Paper presented at NWAV. XXIII, Stanford Unıversity

Ash, Sharon (1988) Speaker identıfication in sociolınguistics and crımınal law In Kathleen Ferrara (ed ), Linguistic change and contact Proceedings of NWAV-XVI, 25-33 Austin Department of Linguistics, University of Texas

ASHA (1983) Position paper Social dialects Asha (American Speech-Language-Hearing Assocration) 25 23-24 
Bailey, Beryl (1965). Toward a new perspective in Negro English dialectology. American Speech 40:171-77.

Bailey, Guy (1993). A perspective on African American English. In Dennis Preston (ed.), American dialect research, 287-318. Amsterdam: Benjamins.

Bailey, Guy, \& Maynor, Natalie (1987). Decreolization? Language in Society 16:449-73. (1989). The divergence controversy. American Speech 64:12-39.

Ball, Arnetha F. (1992). Cultural preference and the expository writing of African American adolescents. Written Communication 9:501-32.

Baltimore (1993). Handbook on language differences and speech and language pathology. Baltimore: Baltimore City Public Schools, Department of Support and Special Pupil Services.

Baratz, Joan C., \& Shuy, Roger W. (1969), eds. Teaching Black children to read. Washington, DC: Center for Applied Linguistics.

Battistella, Edwin (1996). The LSA guidelines for nonsexist language. Paper presented at the symposium on "Addressing bias in linguistic example sentences: Are guidelines necessary?" Linguistic Society of America, San Diego.

Baugh, John (1979). Linguistic style-shifting in Black English. Dissertation, University of Pennsylvania.

(1980). A re-examination of the Black English copula. In Labov 1980:83-106.

(1981). Design and implementation of language arts programs for speakers of nonstandard English. In Bruce Cronell (ed.), Perspectives for a national neighborhood literacy program: The linguistic needs of linguistically different children, 17-43. Los Alamitos, CA: South West Regional Laboratory. Press. (1983). Black street speech: Its history, structure and survival. Austin: University of Texas

(1987). The role of BE copula analyses in the development of a comprehensive linguistic theory. Paper presented at NWAV-XV, Stanford University.

(1988). Language and race: Some implications for linguistic science. In Frederick J. Newmeyer (ed.), Linguistics: The Cambridge survey, IV. Language: The sociocultural context, 64-74. Cambridge \& New York: Cambridge University Press.

(1997). Linguistics, education and the law: Educational reform for African-American language minority students. To appear in Mufwene et al. (eds.)

Bell, Allan (1984). Language style as audience design. Language in Society 13:145-204. (1995). Review of Biber \& Finegan 1994. Language in Society 24:265-70.

Bereiter, Carl, \& Engelmann, Siegfried (1966). Teaching disadvantaged children in the pre-school. Englewood Cliffs, NJ: Prentice-Hall.

Bergvall, Victoria L. (1996). "Merely data"? Reflections on/of bias in constructed linguistic examples. Paper presented at the symposium on "Addressing bias in linguistic example sentences: Are guidelines necessary?" Linguistic Society of America, San Diego.

Biber, Douglas, \& Finegan, Edward (1994), eds. Perspectives on register. Oxford \& New York: Oxford University Press.

Blake, Renée (1997). Defining the envelope of linguistic variation: The case of "don't count" forms in the copula analysis of African American Vernacular English. Language Variation and Change 9:57-80.

Brooks, Charlotte K. (1985), ed. Tapping potential: English and language arts for the Black learner. Urbana, IL: National Council of Teachers of English.

Burling, Robbins (1973). English in black and white. New York: Holt.

Butters, Ronald R. (1989). The death of Black English: Divergence and controversy in black and white vernaculars. Frankfurt: Lang.

(1997). "What is about to take place is a murder": Constructing the racist subtext in a small-town Virginia courtroom. To appear in New studies of language and society, ed. by Joy Peyton \& Peg Griffin. Creskill, NJ: Hampton.

, et al. (1993). The imitation of dialect for illegal purposes: An empirical study. Paper presented at NWAV-XXII, University of Ottawa.

Cameron, Deborah (1992). "Respect, please!": Investigating race, power and language. In Cameron et al. 1992:113-30.

, et al. (1992). Researching language: Issues of power and method. London: Routledge.

$\overline{\mathrm{CCCC}}(1978)$. Committee on the CCCC Language Statement: Students' right to their own lan- 
guage. In Margaret A. Lourie \& Nancy Faires Conklin (eds.), A pluralistic nation: The language issue in the United States, 314-28. Rowley, MA: Newbury House.

Cedergren, Henrietta J., \& Sankoff, David (1974). Variable rules: Performance as a statistical reflection of competence. Language 50:333-55.

Chambers, J. K. (1995). Sociolinguistic theory. Oxford: Blackwell.

Chambers, John W., Jr. (1983), ed. Black English: Educational equity and the law. Ann Arbor: Karoma.

Ching, Marvin K. L. (1987). How fixed is fixing to? American Speech 62:332-45.

Cole, Lorraine (1983). Implications of the position on social dialects. Asha 25:25-27.

Conroy, Pat (1972). The water is wide. Boston: Houghton Mifflin.

Craig, Colette G. (1992). Fieldwork on endangered languages: A forward look at ethical issues. Paper presented at the XVth International Congress of Linguists, Université Laval, Québec. (1995). The Rama language project of Nicaragua: A 10-year perspective. Paper presented at the Linguistic Society of America, New Orleans.

Cukor-Avila, Patricia, \& Bailey, Guy (1995). Grammaticalization in AAVE. Berkeley Linguistics Society, 21:401-13.

Dayton, Elizabeth (1994). The be element in vernacular African-American English be done. Paper presented at the Linguistic Society of America, Boston.

DeStephano, Johanna (1973), ed. Language, society and education: A profile of Black English. Worthington, $\mathrm{OH}$ : Charles A. Jones.

Dillard, J. L. (1972). Black English: Its history and usage in the United States. New York: Random House.

(1992). The development of Black English. London: Longman.

Dumas, Bethany (1990). Voice identification in a criminal law context. American Speech 65:341-48.

Duneier, Mitchell (1994). Andrea's dream, part 5. Chicago Tribune, Dec. 29, sec. 1, p. 14.

Edwards, Walter F. (1991). A comparative description of Guyanese Creole and Black English preverbal aspect marker done. In Edwards \& Winford 1991:240-55.

(1992). Sociolinguistic behavior in a Detroit inner-city black neighborhood. Language in Society $21: 93-115$.

\& Winford, Donald (1991), eds. Verb phrase patterns in Black English and creole. Detroit: Wayne State University Press.

Farrell, T. J. (1983), IQ and Standard English. College Composition and Communication 34:470-84.

Fasold, Ralph W. (1972). Tense marking in Black English: A linguistic and social analysis. Arlington, VA: Center for Applied Linguistics. 56:163-89.

(1981). The relation between Black and White speech in the south. American Speech

\& Shuy, Roger W. (1970), eds. Teaching Standard English in the inner city. Washington, DC: Center for Applied Linguistics. versity Press.

(1975). Analyzing variation in language. Washington, DC: Georgetown Uni-

\& Wolfram, Walt (1970). Some linguistic features of Negro dialect. In Fasold \& Shuy 1970:41-86.

et al. (1987). Are black and white vernaculars diverging? Papers from the NWAVE-XVI panel discussion. American Speech 62:3-80.

Fischer, John L. (1958). Social influences on the choice of a linguistic variant. Word 14:47-56.

Fleischman, Suzanne (1990). Tense and narrativity: From medieval performance to modern fiction. Austin: University of Texas Press.

Folb, Edith (1980). Running down some lines. Cambridge, MA: Harvard University Press.

Fordham, Signithia, \& Ogbu, John U. (1986). Black students' school success: Coping with the "burden of 'acting White'," Urban Review 18:176-206.

Foster, Herbert L. (1986). Ribbin', jivin', and playin' the dozens: The persistent dilemma in our schools. Cambridge, MA: Ballinger.

Foster, Michele (1989). "It's cookin' now": A performance analysis of the speech events in an urban community college. Language in Society 18:1-29.

Fries, Charles C. (1962). Linguistics and reading. New York: Holt, Rinehart \& Winston. 
Galura, Joseph et al (1993), eds PRAXIS II Service-learning resources for university students, staff and faculty Ann Arbor Office of Community Service Learnıng Press, University of Michigan

Gıles, Howard (1979) Ethnicity markers in speech In Klaus R Scherer \& H Gıles (eds), Social markers in speech, 251-89 Cambridge \& New York Cambridge Unıversity Press

Green, Lisa (1993) Topics in African-American English The verb system analysis Dissertatıon, University of Massachusetts, Amherst

Gumperz, John J (1982a) Ethnic style in political rhetoric In his Discourse strategies, 187203 Cambridge \& New York Cambridge University Press

(1982b), ed Language and social tdentity Cambridge \& New York Cambridge Unıversity Press

, et al (1979) Crosstalk A siudy of cross-cultural communication Southall, Middlesex National Centre for Industrial Language Traınıng

Guy, Gregory (1980) Variation in the group and the individual The case of final stop deletion In Labov 1980 1-36

(1991) Explanation in variable phonology An exponential model of morphological constraints Language Variation and Change 3 1-22

(1994) Violable is variable Principles, constraints and linguistıc variation Paper presented at NWAV-XXIII, Stanford University

Hall, William S, et al (1979) Story recall in young Black and White children Effects of racial group membership, race of experımenter, and dialect In Wade Boykin et al (eds), Research directions of Black psychologists, 253-65 New York Russell Sage Foundation

Harrıs, Ovetta, et al (1995) A select bibliography of research on Africanızed Englısh and education Linguistics and Education 7 151-56

Hinton, Leanne (1994) Afterword Linguists and the Califorma languages In her Flutes of fire Essays on California Indlan languages, 249-54 Berkeley Heyday Books

Hollıngshead, August B , \& Redlıch, F C (1958) Social class and mental ıllness A community study New York Wiley

Holm, John (1976) Copula variability on the Afro-American contınuum Conference Preprints, First Annual Meeting of the Society for Caribbean Lingustics, Turkeyen, Guyana, compiled by George Cave, 301-9 Georgetown Linguistics Section, Department of Englısh, University of Guyana

(1984) Variabılity of the copula in Black English and its creole kın American Speech $59291-309$

Holmes, Janet (1992) An introduction to sociolinguistics London Longman

Honnet, Ellen Porter, \& Poulsen, Susan J (1989) Princtples of good practice for combinıng service and learning $A$ Wingspread special report Racine, WI Johnson Foundation

Hoover, Mary (1978) Community attıtudes toward Black Englısh Language in Society 7 65-87 (1991) Using the ethnography of African-American communications in teaching compositıon to bidialectal students In Mary E McGroarty \& Christian J Faltıs (eds ), Languages in schools and society Policy and pedagogy, 465-85 Berlin de Gruyter

, et al (1987) Bias in reading tests for Black language speakers A sociolingustic perspectıve Negro Educatıonal Review 38 91-98

Hopper, Paul J , \& Traugott, Elızabeth Closs (1993) Grammaticalizatıon Cambridge \& New York Cambridge University Press

Howard, Jeffrey (1993a) Community service learning in the curnculum In Howard 1993b 3-12 (1993b), ed PRAXIS I A faculty casebook on community service learning Ann Arbor Office of Community Service Learnıng Press, University of Michıgan

Hudson, Richard A (1996) Sociolinguistics 2nd ed Cambridge \& New York Cambridge Unıversity Press

Information Please Almanac (1996) 49th ed Boston Houghton Mifflin

Jackson, Bruce (1974) Get your ass in the water and swim like me Cambridge, MA Harvard University Press

Jones, Charısse (1995) Crack and punıshment Is race the 1ssue? New York Times, Saturday, Oct 28,1995 , pp 1,9

Jupp, T C, et al (1982) Language and disadvantage The hidden process In Gumperz $1982 b 232-56$ 
Keesıng, Roger M (1988) Melanesian Pidgın and the Oceanic substrate Stanford, CA Stanford University Press

Kerbo, Harold (1983) Social strattication and inequaltty New York McGraw-Hill

Kiparsky, Paul (1994) An optımality-theoretıc perspectıve on varıable rules Paper presented at NWAV-XXIII, Stanford University

Kochman, Thomas (1972), ed Rappın' and stylın' out Urbana University of lllınors Press (1981) Black and White styles in conflict Chicago University of Chicago Press

Labov, Teresa (1982) Social structure and peer termınology in a Black adolescent gang Language in Society 11 391-411

Labov, William (1963) The social motivation of a sound change Word 19 273-309 (1966) The social stratification of English in New York City Washington, DC Center for Applied Linguistics (1969) Contraction, deletıon, and inherent varıability of the Englısh copula Language $45715-62$ (1970) The logic of nonstandard English In F Wilhams 1970 153-89

(1972) Language in the inner city Studies in the Black English vernacular Philadelphia Unuversity of Pennsylvanıa Press (1976) Systematically misleading data from test questions Urban Review 9 146-69 (1980), ed Locatıng language in tıme and space New York Academic Press (1982) Objectivity and commitment in linguistic science The case of the Black English trial in Ann Arbor Language in Society 11 165-201 (1988) The judicial testing of linguistic theory In Deborah Tannen (ed ), Linguistics in context Connecting observatıon and understanding, 159-82 Norwood, NJ Ablex (1994) Can reading fallure be reversed? A linguistic approach to the question In VivIan Gadsden \& Daniel Wagner (eds ), Literacy among African-American youth, 39-68 Creskill, NJ Hampton Press

(1995) Untitled paper presented at the Amherst Conference on African American Englısh, held at the University of Massachusetts , \& Harris, Wendell A (1986) De facto segregation of black and white vernaculars In David Sankoff (ed ), Diversity and diachrony, 1-24 Amsterdam Benjamins , et al (1965) A preliminary study of the structure of English used by Negro and Puerto Rican speakers in New York City (Cooperative Research Project no 3091) New York Columbia University \& Waletzky, Joshua (1967) Narrative analysis In June Helm (ed ), Essays on the verbal and visual arts, 12-44 Seattle University of Washington Press , et al (1968) A study of the non-standard English of Negro and Puerto Rican speakers in New York City (Cooperatıve Research Project no 3288 ) New York Columbia University

Leaverton, Lloyd (1973) Dialectal readers Rationale, use and value In James L Laffey \& Roger Shuy (eds ), Language differences Do they interfere?, 114-26 Newark, DE International Reading Association

Legum, Stanley, et al (1971) The speech of young black children in Los Angeles (Technical report no 33 ) Los Angeles Southwestern Regional Laboratory

Le Page, Robert B (1968) Problems to be faced in the use of English as a medium of education in four West Indian territories In Joshua A Fishman et al (eds), Language problems of developing natıons, 431-43 New York Wiley

Lind, E A , \& O'Barr, W M (1979) The social significance of speech in the courtroom In Howard Giles \& Robert N St Clair (eds ), Language and social psychology, 66-87 Oxford Blackwell

Lippı-Green, Rosına (1994) Accent, standard language ideology, and discrımınatory pretext in the courts Language in Society 23 163-98

Macaulay, Monica, \& Brice, Colleen (1996) John gives it, Mary gets it The distribution of gendered NPs in syntactic examples Paper presented at the symposium on "Addressing bias in linguistic example sentences Are guidelines necessary?" Linguistic Society of America, San Diego

Maroney, Oanh H , et al (1994) Black dialect versus Standard English in education In John R Rickford et al (eds ), The AAVE Happenin' 1994 Student papers from Linguistics 73, 
African American Vernacular English, 3-45. Stanford: Department of Linguistics, Stanford University.

Martin, Stefan E. (1992). Topics in the syntax of nonstandard English. Dissertation, University of Maryland, College Park.

Matsuda, Mari J. (1991). Voices of America: Accent, anti-discrimination law, and a jurisprudence for the last reconstruction. Yale Law Journal 100:1329-1407.

McDavid, Raven I., \& McDavid, Virginia G. (1951). The relationship of the speech of Negroes to the speech of whites. American Speech 26:3-16.

Michaels, Sarah (1981). "Sharing time": Children's narrative styles and differential access to literacy. Language in Society 10:423-42.

Milroy, James (1984). Sociolinguistic methodology and the identification of speakers' voices in legal proceedings. In Peter Trudgill (ed.), Applied linguistics, 51-72. London \& Orlando: Academic Press.

, \& Milroy, Lesley (1992). Social network and social class: Toward an integrated sociolinguistic model. Language in Society 21:1-26.

Milroy, Lesley (1980). Language and social networks. Oxford: Blackwell.

Mitchell-Kernan, Claudia (1969). Language behavior in a black urban community. (Working paper no. 23.) Berkeley: Language Behavior Research Laboratory.

Moonwomon-Baird, Birch (1996). Where are Adam and Steve, Fatima and Eve? Heterosexism in example sentences. Paper presented at the symposium on "Addressing bias in linguistic example sentences: Are guidelines necessary?" Linguistic Society of America, San Diego.

Morgan, Marcyliena (1991). Indirectness and interpretation in African-American women's discourse. Pragmatics 1:421-51.

(1994a). The African-American speech community: Reality and sociolinguists. In Marcyliena Morgan (ed.), The social construction of identity in creole situations, 121-48. Los Angeles: Center for Afro-American Studies, UCLA.

(1994b). Conversational signifying: Grammar and indirectness among African-American women. Paper presented at Interaction and Grammar workshop, Los Angeles.

Morganthau, Tom, \& Carroll, Ginny (1996). Affirmative action: The backlash wars. Newsweek, April 1, pp. 54-55.

Mufwene, Salikoko S. (1992). Ideology and facts on African American Vernacular English. Pragmatics 2:141-66.

; Rickford, John R.; Bailey, Guy; \& Baugh, John (1997). African American English. London: Routledge, to appear.

O'Barr, William M. (1982). Linguistic evidence: Language, power, and strategy in the courtroom. New York: Academic Press.

Österberg, Tore (1961). Bilingualism and the first school language: An educational problem illustrated by results from a Swedish language area. Umeâ, Sweden: Västernbottens Tryckeri.

Poplack, Shana, \& Sankoff, David (1987). The Philadelphia story in the Spanish Caribbean. American Speech 62:291-314.

, \& Tagliamonte, Sali (1991). African-American English in the diaspora: Evidence from old-line Nova Scotians. Language Variation and Change 3:301-39.

Rampton, M. B. H. (1992). Scope for empowerment in sociolinguistics? In Cameron et al. 1992:29-64.

Rick ford, Angela E. (1996). Cognition, comprehension and critical evaluation in a multicultural classroom: A study in literary analysis and appreciation. Stanford University dissertation. [To appear, University Press of America.]

Rickford, John R. (1975). Carrying the new wave into syntax: The case of Black English BIN. In Fasold \& Shuy 1975:162-83.

(1977). The question of prior creolization in Black English. In Albert Valdman (ed.), Pidgin and creole linguistics, 190-221. Bloomington: Indiana University Press.

(1979). Variation in a creole continuum: Quantitative and implicational approaches. Dissertation, University of Pennsylvania.

(1985). Ethnicity as a sociolinguistic variable. American Speech 60:99-125.

(1986). The need for new approaches to social class analysis in sociolinguistics. Language and Communication 6:215-21. 
(1991). Grammatical variation and divergence in Vernacular Black English. In Marinel Gerritsen \& Dieter Stein (eds.), Internal and external factors in syntactic change, 175-200. Berlin: de Gruyter.

(1995). AAVE and the Creole Hypothesis: Reflections on the state of the issue. Paper presented at NWAV-XXIV, University of Pennsylvania.

(1996). Regional and social variation. In Sandra Lee McKay \& Nancy H. Hornberger (eds.), Sociolinguistics and language teaching, 151-94. Cambridge \& New York: Cambridge University Press.

\& Blake, Renee (1990). Copula contraction and absence in Barbadian English, Samaná English, and Vernacular Black English. Berkeley Linguistics Society 16:257-68. , \& Greaves, Barbara (1978). Non-standard words and expressions in the writing of Guyanese school children. In John R. Rickford (ed.), A festival of Guyanese words, 40-56. Georgetown: University of Guyana.

, \& Green, Lisa A. (1997). African American Vernacular English. Cambridge \& New

York: Cambridge University Press, to appear.

\& McNair-Knox, Faye (1994). Addressee and topic-influenced style shift: A quantitative sociolinguistic study. In Biber \& Finegan 1994:235-76.

, \& Rickford, Angela E. (1995). Dialect readers revisited. Linguistics and Education 7:107-28.

, \& Theberge-Rafal, Christine (1996). Preterit had in the narratives of African-American preadolescents. American Speech 71:227-54.

, et al. (1991). Rappin on the copula coffin: Theoretical and methodological issues in the analysis of copula variation in African American Vernacular English. Language Variation and Change 3:103-32.

Rieber, Robert W., \& Stewart, William A. (1990), eds. The language scientist as expert in the legal setting. (Annals of the New York Academy of Sciences, 606.) New York.

Roberts, Celia, et al. (1992). Language and discrimination: $A$ study of communication in multiethnic workplaces. London: Longman.

Romaine, Suzanne (1982). Socio-historical linguistics: Its status and methodology. Cambridge \& New York: Cambridge University Press.

Rouch, Roger L., \& Birr, Shirley (1984). Teaching reading: A practical guide of strategies and activities. New York: Teachers College Press.

Schiffrin, Deborah (1981). Tense variation in narrative. Language 57:45-61.

Shuy, Roger W. (1965), ed. Social dialects and language learning. Champaign, IL: National Council of Teachers of English.

(1986). Language and the law. Annual Review of Applied Linguistics 7:50-63.

, et al. (1967). Linguistic correlates of social stratification in Detroit speech. Final Report, Cooperative Research Project 6-1347, US Office of Education.

Simpkins, Gary A., \& Simpkins, Charlesetta (1981). Cross-cultural approach to curriculum development. In Smitherman 1981a:221-40. Mifflin.

, et al. (1977). Bridge: $A$ cross-cultural reading program, Ist ed. Boston: Houghton

Singler, John (1991). Copula variation in Liberian Settler English and American Black English. In Edwards \& Winford, 129-64.

Sledd, James (1969). Bidialectalism: The linguistics of White supremacy. English Journal 58:1307-15.

Smith, Jessie Carney, \& Johns, Robert L. (1995). Statistical record of Black America. New York: Gale Research.

Smitherman, Geneva (1981a), ed. Black English and the education of Black children and youth. Detroit: Center for Black Studies, Wayne State University.

(1981b). Introduction. In Smitherman 1981a:11-36.

(1986). Talkin and testifyin: The language of Black America. Detroit: Wayne State University Press.

(1994). "The blacker the berry, the sweeter the juice": African-American student writers and the national assessment of educational progress. In Anne Haas Dyson \& Celia Genishi (eds.), The need for story: Cultural diversity in classroom and community, 80-101. Urbana, IL: National Council of Teachers of English. 
(1995) If I'm lyın, I'm flyın An introduction to the art of the snap In James Percelay et al (eds ), Double snaps, 14-33 New York Quill/Willam Morrow

Smitherman-Donaldson, Geneva (1988) Discrımınatory discourse on Afro-American speech In Smitherman-Donaldson \& van Dijk 1988 144-75

, \& van Diık, Teun A (1988), eds Discourse and discrimination Detroit Wayne State Unıversity Press

Spears, Arthur K (1982) The Black Englısh semt-auxilıary come Language 58 850-72

Starks, Judith A (1983) The Black English controversy and its implications for addressing the educational needs of Black children The cultural linguistic approach In Chambers 1983 97-132

Stewart, Willıam A (1964), ed Non-standard speech and the teaching of English Washıngton, DC Center for Applied Linguistics

(1969) On the use of Negro dialect in the teaching of reading In Baratz \& Shuy 1969 156-219

(1970) Toward a history of American Negro dialect In F Willams 1970 351-79

(1975) Teachıng Blacks to read against theır will In Phılıp A Luelsdorff (ed ), Lınguistlc perspectives on Black English, 107-31 Regensburg, Germany Hans Carl

Tagliamonte, Salı, \& Poplack, Shana (1988) How Black English Past got to the present Language in Society 17 513-33

Taylor, Orlando L (1986), ed Nature of communication disorders in culturally and linguistically diverse populations San Diego, CA College Hill Press

, \& Lee, Dorian L (1987) Standardized tests and African Americans Communication and language issues Negro Educational Review 38 67-80

, \& Matsuda, Maryon M (1988) Storytelling and classroom discrimination In Smitherman-Donaldson \& van Dijk 1988 206-20

Terrell, Sandra L, \& Terrell, Francis (1983) Effects of speakıng Black English upon employment opportunities Asha 26 27-29

Theberge, Christıne (1988) Some sixth grade rappers, writers, and readers Senıor honors essay, Department of Linguistics, Stanford University

Trudgill, Peter (1995) Sociolinguistics 3rd ed London Penguin

US (1995) Statistical abstract of the United States 115th ed Washington, DC Bureau of the Census

Vaughn-Cooke, Fay (1983) Improving language assessment in minority children Asha 25 29-34

Walters, Keith (1995) Contesting representations of African-American language Keynote address, SALSA III conference, University of Texas, Austın

Wardhaugh, Ronald (1992) An introduction to sociolinguistics, 2nd ed Oxford Blackwell

Williams, Frederick (1970), ed Language and poverty Chicago Markham

Willams, Glyn (1992) Soctolınguistics A sociological critıque London Routledge

Williams, Robert L (1975), ed Ebonics The true language of Black folks St Louis Robert L Williams \& Associates

, \& Rivers, L Wendell (1975) The effects of language on the test performance of Black children In $\mathrm{R}$ Williams (ed ), 96-109

Winford, Donald (1992a) Another look at the copula in Black English and Carıbbean creoles American Speech 67 21-60

(1992b) Back to the past The BEV/creole connection revisited Language Variation and Change 4 311-57

(1995) Decreolization, divergence, and dialect distance in African American Vernacular English Paper presented at the Amherst Conference on African American Englısh, Unıversity of Massachusetts

Wolfram, Walt (1969) A sociolinguistic descriptıon of Detrout Negro speech Washıngton, DC Center for Applied Linguistics

(1975) Variable constraints and rule relations In Fasold \& Shuy 1975 70-88

(1976) Levels of sociolinguistic bias in testing In Deborah S Harrison \& Tom Trabasso (eds ), Black English A seminar, 263-87 Hillsdale, NJ Erlbaum

(1986) Black-White dimensions in sociolinguistic test bias In Michael B Montgomery \& Guy Bailey (eds ), Language variety in the south, 373-85 University University of Alabama Press 


\section{UNEQUAL PARTNERSHIP}

(1991) Dialects and American English Englewood Chiffs, NJ Prentice-Hall

(1993) A proactive role for speech-language pathologists in sociolinguistic education Language, Speech and Hearing Service in Schools 24 181-85

, \& Christian, Donna (1989) Dialects and education Issues and answers Englewood Cliffs, NJ Prentice Hall , \& Clarke, Nona (1971), eds Black-White speech relatıonshıps Washıngton, DC Center for Applied Linguistıcs

, \& Schillıng-Estes, Natalıe (1995a) Dialect preservatıon and community collaboration

A proactive program Paper presented at the Linguistic Society of America, New Orleans

Science Foundation (1995b) Linguistics and the human capital initiative Report to the National 